\title{
The Influence of Architecture Students' Learning Approaches on their Academic Performance in Two Nigeria Universities
}

\author{
Gabriel Sen* \\ Covenant University, Nigeria \\ https://orcid.org/0000-0002-7039-1903 \\ Albert Adeboye
Olabisi Onabanjo University, Nigeria
https://orcid.org/0000-0003-2985-1426 \\ Oluwole Alagbe \\ Covenant University, Nigeria \\ https://orcid.org/0000-0003-2779-1861
}

\begin{abstract}
The paper was a pilot study that examined learning approaches of architecture students; variability of approaches by university type and gender and; influence of architecture students' learning approaches on their academic performance. The sample was 349 architecture students from two universities. Descriptive and statistical analyses were used. Results revealed predominant use of deep learning approaches by students. Furthermore, learning approaches neither significantly differed by university type nor gender. Regression analysis revealed that demographic factors accounted for $2.9 \%$ of variation in academic performance $\left(\mathrm{F}_{(2,346)}=6.2, \mathrm{p}=0.002, \mathrm{R}^{2}=0.029, \mathrm{f}^{2}\right.$ $=0.029)$ and when learning approaches were also entered the model accounted for $4.4 \%$ of variation in academic performance $\left(\mathrm{F}_{(14,334)}=2.2, \mathrm{p}\right.$ $\left.=0.009, \mathrm{R}^{2}=0.044, \mathrm{f}^{2}=0.044\right)$. Deep learning approaches significantly and positively influenced variation in academic performance while surface learning approaches significantly and negatively influenced academic performance. This implies that architectural educators should use instructional methods that encourage deep approaches. Future research needs to use larger and more heterogeneous samples for confirmation of results.
\end{abstract}

Keywords: architecture students; students' learning approaches; deep learning approaches; surface learning approaches; academic performance

*Corresponding Author: Gabriel Sen; Email: gpnlsen@gmail.com; gabriel.sen@stu.cu.edu.ng. 


\section{Introduction}

Universities in Nigeria and even worldwide desire that students pass their examinations in order to graduate on time. Failure of students to graduate on time results in substantial financial losses and several administrative problems. Architectural educators are, therefore, always looking for strategies that would help students complete their educational careers on time. One of such strategies is in studying the learning approaches of architecture students. Results from previous studies have shown that, learning approaches of students in higher education significantly influence academic performance (Carstensen, Ødegaard and Bonsaksen, 2018; Öhrstedt \& Lindfors, 2019). Puteh et al. (2018) on the other hand reported that learning approaches do not predict academic performance. Knowledge of the relationship between architecture students' learning approaches and their academic performance will undoubtedly reveal the priority that architectural education should give to learning approaches. This pilot study is meant to achieve this aim.

\subsection{Student Learning Approach}

Learning approach is the intention and strategy adopted by students in acquisition of knowledge (Biggs \& Tang, 2007). Learning approaches are not an inherent but acquired trait or strategy determined by contextual demands (Chonkar, Ha \& Chu, 2018). Furthermore, the learning approach of a student is characterised by a change in study behaviours dictated by the student's perception of the learning task (Dilek \& Noor, 2015). Previous studies have categorised learning approaches into two: surface learning approach and deep learning approach (Ayalp, 2015; Howie \& Bagnell, 2013).

Surface learning approach is depicted by the students' behaviour of adopting strategies of memorisation of ideas and facts during studies. Information is studied as unrelated and isolated facts (Shaik et al., 2017).The emphasis is not that of understanding the underlying principles of the information, but rather on rote learning. Ayalp (2015) opines that such a strategy results in the student hardly retaining knowledge after examinations. The surface learning approach is, therefore, extrinsically motivated, which is a kind of motivation due to what the student sees around him (Noori et al., 2020). The student that focuses on the surface approach seeks to overcome tasks with minimum efforts.

Deep learning approach on the other hand is depicted by the student's adoption of aggressive engagement with the materials being studied. The student seeks to relate newly acquired information with precious ideas (Dilek \& Noor, 2015). The student tries to understand the patterns and underlying principles of the study material. In this approach, there is the promotion of deeper reasoning; higher order thinking that is followed by self-directed learning (Rakibul-Islam \& Shahriar Shafiq, 2016). The student adopting a deep learning approach, therefore, goes beyond mere acquisition of knowledge, but analyses, synthesises and evaluates the subject matter. The subject matter is integrated with real life situations and compared with the student's personal experience. Although this method focuses on the subject matter, the student is still mindful that meaning is conveyed by words, text and formulae. The deep learning approach is intrinsically motivated, which is a type of motivation that is from the student, 
but not from what the student sees externally (Noori et al., 2020). Danaci (2014) reports that, in architectural education, the failure of students in adopting deep learning approach results in their inability to defend their designs. This obviously affects their ability of passing their examinations and also results to deficiencies in their future careers. Suffice it to mention that the architectural curriculum emphasises vocational skills which, according to Danaci (2014), should require a deep learning approach.

\subsection{Student Learning Approach and Academic Performance}

Previous studies have shown that learning approach is a process factor of Biggs's 3P theory that affects the learning outcome of the students (Song, 2018). According to the theory, three factors of presage, process and product are responsible for learning in educational institutions. The presage factor could refer to demographic variables like university type and gender. It could also include learning environment. The process factor, on the other hand, refers to students' learning approaches while the product factor refers to the student's learning outcome such as the student's academic performance. The academic performance could be expressed in form of students' Cumulative Grade Point Average (CGPA). The theory further postulates that the personal factor can directly affect the students' learning outcome. Also, that the process factor (students' learning approach) can also directly affect the students' learning outcome. Furthermore, the students' learning approach can influence the students' learning outcome even when the presage factor is acting as the intervening variable. Based on the 3P theory, studies have been carried out on learning approaches on the premise that the approach scores of the students could be an index of their teaching quality. By implication, the learning approach scores of the student are useful in helping the teacher realise better ways of meeting the students' needs. This could be in terms of assessment, curriculum, overload, teaching methods and learning environment (Entwistle, 1988).

Previous studies have, therefore, investigated the predominant learning approaches of students in higher education. Hussin, Hamed and Md-Jam (2017) investigated the predominant learning approaches of engineering students at University of Technology Mara from four different faculties. The findings revealed that engineering students predominantly use deep learning approach. Kamath et al. (2018) also investigated the learning approaches of second year medical students and the findings also revealed that the students adopted a deep learning approach. Arsaythamby et al. (2015), on the contrary, reported a predominant use of surface learning approaches by English undergraduate students among University Utara, Malaysia.

The findings from previous studies have also shown that students' learning approaches could be affected by the school type. Khan et al. (2020) investigated how peculiarities in school leadership and teaching could affect students' learning experiences, which will inadvertently affect their learning approaches. Concomitantly, Leung, Fang and Lu (2015) compared the learning approaches of universities in mainland China and Hong Kong City and found learning approaches to differ significantly in terms of university type. This was, however, 
contrary to Ayalp (2015) who compared engineering students' learning approaches from four universities and found no significant difference in approaches.

Previous studies have also identified the need to explore gender differences in learning approach research. Rosander and Martin (2012) have shown that gender stratification affects school experiences. It is, therefore, essential that this pilot study is done with due recognition of gender stratification. Several studies have previously found no differences of learning approaches by gender. Keithia et al. (2011) reported no gender differences in learning approaches in first year psychological students. Such was also the findings of Arteche et al. (2009) on psychology students, both from five British and two American universities. Other previous studies, however, have identified differences in learning approaches based on gender (Biggs, 1987).

Previous studies have further examined the impact of learning approaches on academic performance and have found varied results. Salamonsun et al. (2013) reported that deep and surface learning approaches from across five different disciplines of Nursing, Engineering, Mechanical, Health Sciences and Medical Chemistry significantly affected the students' academic performance. Surface learning approach negatively predicted students' performance $(B=-0.13, p=$ 0.001) while deep learning approach positively predicted the students' performance. Also, in a study on a sample of education students, Cetin (2016) reported a positive relationship between deep learning approach and students Grade Point Average (GPA) and a negative relationship between the surface approach and the student's GPA. In a sample of undergraduate students of philosophy, education and psychology, Karagiannopoulou and Milienos (2015) also found that surface learning approach statistically, significantly and negatively predicted students' GPA, whereas the deep learning approach had no effect on the students 'GPA. Choy, O'Grady and Rotgans (2012) found that approaches to learning are weak predictors to academic achievement. Using a sample of students drawn from four faculties that included architecture, planning and survey, science computer and mathematics, arts and accounting, Moh'd et al. (2015) reported no prediction of learning approaches on academic performance. Such were also the findings of Bonsaksen et al. (2017) in a study which involved a sample of undergraduate occupational therapy students from four countries, Australia, Norway, Hong-Kong and Singapore.

As could be seen from the above literature, previous studies on student learning approaches are seemingly conducted mainly in areas outside the discipline of architecture. Even when such studies included architecture students in their sample, the proportion of students from other disciplines remained dominant. Moreover, the apparent discrepancies in results created a need for more research in learning approaches and particularly in the architectural discipline. The present pilot study is meant to fill this gap. 


\subsection{Research Questions and Hypotheses}

This pilot study is meant to address three questions:

1) What are the predominant learning approaches of architecture students?

2) What are the disparities in students' learning approaches in terms of demographic factors of university types and gender?

3) What is the influence of the architecture students' learning approaches on the cumulative grade points average (CGPA) after accounting for demographic factors of university type and gender?

The study made use of the following hypotheses;

\section{Hypothesis H1:}

There is a statistically significant difference between learning approach scores in terms of university type. The associated hypothesis $\left(\mathrm{H}_{1}\right)$ is that there is no statistically significant difference between learning approach scores in terms of university type.

\section{Hypothesis H2:}

There is a statistically significant difference between male and female students' learning approaches scores. The associated null hypothesis $\left(\mathrm{H} 2_{0}\right)$ is that there is no statistically significant difference between male and female learning approach scores.

\section{Hypothesis H3:}

Learning approaches account for a variance in academic performance when demographic variables of gender and universities types are controlled for. The associated null hypothesis $\left(\mathrm{H}_{0}\right)$ is that learning approaches do not account for any variance in academic performance when the demographic variables of gender and university type are controlled for.

\section{Materials and Methods}

This section of the paper refers to the procedure and the specific tools that were used in carrying out this study. This is presented in the following subheadings.

\subsection{Research Strategy}

A cross-sectional survey was adopted for this pilot study. According to Sedgwick (2014), this method of survey has the advantage of not requiring too much time in capturing data. Data were, therefore, collected once for each of the two universities studied. This was during the first semester of 2018/2019 academic year.

\subsection{Participants}

Census sampling techniques was used. The technique involved all the undergraduate architecture students in second, third and fourth years. The sample also included postgraduate students of architecture in the second year. These were all from Rivers State University, Portharcourt (RSU) and University of Uyo, Uyo (UNIUYO). The first-year undergraduate students were deliberately left out of the study since the school curricular indicated that the real architectural education starts in the second year. The first-year postgraduate students were also left out of the study since at the time of study the universities 
had not fully admitted their first-year postgraduate students. Moreover, even those admitted had not obtained any CGPA. The choice of the universities was purposive. RSU as a state government sponsored university was chosen to represent the state government owned universities. University of Uyo, Uyo (UNIUYO) as a federal government owned university was chosen to represent the federal government owned universities. The emphasis of the pilot study was on public universities.

\subsection{Data Collection Tools}

Quantitative data for the study were collected using anonymous questionnaire that had two parts, as displayed in appendix I. The first part collected information on the students' personal factors of university type, gender and their current CGPA. The self-report method was adopted due to the administrative difficulties encountered in obtaining access to students' academic records. The second part of the questionnaire had the Biggs, Kember and Leung (2001) Revised Student Study Process Questionnaire (R-SPQ-2F). This questionnaire has 20 items that are equally divided into two main subscales, surface learning approach and deep learning approach. The subscale for surface learning approach has 10 items with five items meant for surface motive and the other five items meant for surface strategy. An example of items measuring the surface motive approach is; "My aim is to pass the course while doing as little work as possible" and an example of the item measuring surface strategy is "I only study seriously what's given out in class or in the course outlines". The subscale for measuring deep learning approach also has 10 items with five items measuring deep motive and the other five items measuring deep strategy. Example of items measuring the deep motive is; "I find that sometimes studying gives me a feeling of deep personal satisfaction" and the example of the items measuring the deep strategy is; "I find that I have to do enough work on a topic so that I can perform my own conclusions before I am satisfied". The measures are on a five point Likert scale rated from 1-5. ' 1 ' indicates Never or only rarely true of me while 5 indicate salways or almost always true of me. The scoring system is as prescribed by Biggs et al. (2001):

Surface approach score: $\sum$ All surface motive scores + all surface strategy scores. Deep approach score: $\sum$ All deep motive scores + all deep strategy scores.

\subsection{Data Collection Method}

A total of 444 questionnaires were administered on the students, some before their lecture session and others after such sessions. The participants filled the questionnaires within the space of twenty minutes. Only 349 of the questionnaires that were returned and completed were used for the analysis.

\subsection{Data Analysis}

The Cronbach's alpha of the R-SPQ-2F was fully determined to ascertain the reliability of the scale. Descriptive analysis was used to determine the predominant learning approaches of the participants, which answered the first research question. The second and third research questions were transformed into hypotheses $\left[(\mathrm{H} 1-\mathrm{H} 3)\right.$ and $\left.\left(\mathrm{H}_{1}-\mathrm{H}_{3}\right)\right]$. In order to test the first two null hypotheses $\left(\mathrm{H}_{1}\right.$ and $\left.\mathrm{H} 2_{0}\right)$, one way multivariate analysis of variance (MANOVA) was used. Categorical regression was used to test the third null 
hypotheses $\left(\mathrm{H}_{0}\right)$. This was because the dependent variable, CGPA was measured categorically. Students indicated the ranges of their current CGPA. Categorical regression could, therefore, be used as submitted by Choy et al. (2012). The program used for analysis was IBM, SPSS version 21.

\section{Result}

The demographics of the respondents in terms of university type and gender are shown in Table 1:

Table 1: Demographic Analysis of the Respondents

\begin{tabular}{llll}
\hline \multicolumn{2}{l}{ Demographic Information } & Frequency & Percentage \\
\hline \multirow{3}{*}{ University Type } & Rivers State University Portharcourt & 152 & $43.6 \%$ \\
& University of Uyo, Uyo & 197 & $56.4 \%$ \\
& Total & $\mathbf{3 4 9}$ & $\mathbf{1 0 0 \%}$ \\
\multirow{5}{*}{ Gender } & Male & 259 & $74.2 \%$ \\
& Female & 90 & $25.8 \%$ \\
& Total & $\mathbf{3 4 9}$ & $\mathbf{1 0 0} \%$ \\
\hline
\end{tabular}

The Cronbach's alpha value of the R-SPQ-2F instrument revealed 0.781 for deep learning approach and 0.70 for surface learning approach. This, according to Pallant (2011), is good for analysis. When descriptive analysis was used to determine the mean scale of the two learning approaches, the result was as presented in Table 2. Deep learning approach (DA) had predominant scores (M $=33.56, \mathrm{SD}=6.87)$ over surface learning approach $(\mathrm{M}=27.96, \mathrm{SD}=6.65)$.

Table 2. Descriptive Statistics of Approaches Scores

\begin{tabular}{llll}
\hline & N & Mean & Standard Deviation \\
\hline Deep approach & 349 & 33.56 & 6.87 \\
Surface approach & 349 & 27.97 & 6.65 \\
\hline
\end{tabular}

To test for the first null hypotheses $\left(\mathrm{H} 1_{0}\right)$, a one-way multivariate analysis of variance (MANOVA) was also carried out to determine whether the combined students learning approach scores differed in terms of university type. Preliminary checking of assumption for the above analysis sufficed. There was, however, homogeneity of variance-covariance matrices as assessed by Box's M test $(p=0.193)$. Students in RSU and UNIUYO had higher deep learning approach scores $(\mathrm{M}=33.4, \mathrm{SD}=6.52 ; \mathrm{M}=33.7$, $\mathrm{SD}=7.14)$ than their surface learning approach scores $(M=26.7, \mathrm{SD}=7.1 ; \mathrm{M}=28.2, \mathrm{SD}$ $=6.2$ ), respectively. The difference between universities on the combined learning approaches scores was not statistically significant $\mathrm{F}_{(2,346)}=0.446, \mathrm{p}=0.641$; Wilk's ${ }^{\wedge}=$ 0.997; partial $\eta^{2}=0.003$. This shows that the null hypothesis that there is no statistically significant difference between learning approach scores in terms of university type cannot be rejected. The implication is that learning score approaches do not vary by the type of university.

To test for the second null hypotheses $\left(\mathrm{H} 2_{0}\right)$, a one-way multivariate analysis of variance (MANOVA) was carried out to determine whether the differences in learning approaches scale were statistically significant in terms of gender. There was the 
preliminary checking of assumptions for suitability of analysis which revealed that data were normally distributed as assessed by Q-Q plot; there was no serious violation on univariate outliers when trimmed means were inspected against the actual means of the dependent variables [deep approach (mean $=33.56$, trimmed mean $=33.80$; surface approach (mean $=27.96$, trimmed means $=28.01]$. There were no multivariate outliers as revealed by Mahalanobis distance $(p>0.001)$. There was linear relationship as revealed by scatter plot and no multi-collinearity $(r=0.203, p>0.0005)$, and there was also homogeneity of variance-covariance matrices as assessed by Box's $M$ test $(\mathrm{P}=$ 0.155). Male and females had higher deep approach score $(\mathrm{M}=33.5, \mathrm{SD}=71 ; \mathrm{M}=33.7$, $\mathrm{SD}=6.2)$ than surface approaches scales $(\mathrm{M}=28.1, \mathrm{SD}=6.5 ; \mathrm{M}=27.4, \mathrm{SD}=7.2)$, respectively. The difference between male and female students on the combined learning approach scores was not statistically significantly as $\mathrm{F}_{(2,346)}=0.497, \mathrm{p}=0.609$; Wilks' ${ }^{\wedge}=0.997$; partial $\eta^{2}=0.003$. This shows that the null hypothesis that there is no statistically significant difference between male and female learning approach scores cannot be rejected. The implication is that learning approach score do not vary by gender.

In testing for the third null hypothesis $\left(\mathrm{H}_{0}\right)$, categorical regression was first carried out using the students' CGPA as the response and demographic factors of age and university type as predictors. The results as shown in Table 2 revealed that the demographic variable of university type was significant $(\beta=0.178, \mathrm{p}<0.005)$ and this accounted for $2.9 \%$ of variance in academic performance $\left(\mathrm{F}_{(2,346)}=6.2, \mathrm{p}=0.002\right.$, adjusted $\left.\mathrm{R}^{2}=0.029, \mathrm{f}^{2}=0.029\right)$ and when learning approaches were added as variables, the influence of deep learning approach was significant $(\beta=0.22, p<0.005)$, while surface

learning approach did not show any significant influence in academic performance $(\beta=$ $0.134, \mathrm{p}=0.773)$. These all accounted for $4.4 \%$ of the variance in academic performance $\left(\mathrm{F}_{(14,334)}=2.2, \mathrm{p}=0.009\right.$, Adjusted $\left.\mathrm{R}^{2}=0.044, \mathrm{f}^{2}=0.044\right)$. This shows that the null hypothesis $(\mathrm{H} 3)$ that learning approaches do not account for any variance in academic performance when the demographic variables of gender and university type are controlled should be rejected. This shows that learning approaches do influence academic performance even when demographic factor of gender and university are acting as intervening variables.

Table 3. Categorical Regression Results

\begin{tabular}{|c|c|c|c|c|c|c|c|c|}
\hline $\begin{array}{l}\text { Independent } \\
\text { variables }\end{array}$ & & $\begin{array}{c}\text { Standardised } \\
\text { Coefficients Beta } \\
(\beta)\end{array}$ & $\mathbf{F}$ & $\mathbf{p}$ & $\mathbf{f}^{2}$ & $\begin{array}{c}\text { Adjusted } \\
\mathbf{R}^{2}\end{array}$ & $\mathbf{F}$ & $\mathbf{p}$ \\
\hline \multicolumn{9}{|c|}{ Demographic Factors } \\
\hline University & & 0.178 & 12.8 & $0.000^{*}$ & 0.029 & 0.029 & 6.2 & 0.002 \\
\hline Gender & & 0.059 & 1.3 & 0.252 & & & & \\
\hline \multicolumn{9}{|c|}{ Student Learning Approaches } \\
\hline $\begin{array}{l}\text { Deep } \\
\text { approaches }\end{array}$ & learning & 0.229 & 6.9 & $0.000^{*}$ & 0.44 & 0.44 & 2.2 & 0.009 \\
\hline $\begin{array}{l}\text { Surface } \\
\text { approaches }\end{array}$ & learning & -0.134 & -0.08 & .773 & & & & \\
\hline
\end{tabular}




\section{Discussion}

The result of this study has shown that architecture students predominantly use a deep learning approach. This is consistent with the findings of Moh'd et al. (2015) on a study that had a sample that included students of architecture, planning and survey. It revealed predominant scores of deep learning approach $(\mathrm{M}=35.01, \mathrm{SD}=5.715)$ as against the surface learning approach $(\mathrm{M}=30.17, \mathrm{SD}=6.33)$. Ayalp (2015) also reported the predominant use of deep learning approach $(\mathrm{M}=32.21, \mathrm{SD}=5.4)$ over the surface learning approach $(\mathrm{M}=29.07, \mathrm{SD}=6.35)$ on a sample of engineering students. Such also were the findings of Hussin et al. (2017) who used a sample of engineering students and found deep learning approach scores with a mean $(\mathrm{M}=32.8)$ higher than the surface learning approaches scores mean $(M=27.27)$. Comparing this study with other studies in the architectural discipline is rather difficult due to the dearth of similar studies in architectural education. The similarity of this study's result with that of engineering students might not be surprising. This might be due to the similar emphasis on problem-based learning in the two disciplines. Dilek and Noor (2015) have reported that problem-based learning, among other factors like the nature of curriculum and assessment methods, encourages the use of deep learning approaches. It could also mean that the students' predominant use of deep learning approaches is as a result of the collaborative learning occasioned by the design studio which, according to Oluwatayo, Aderonmu and Aduwo (2015), is the sine qua non of architectural education. Collaborative learning, according to Tee-Meng et al. (2016), enhances the use of deep learning approach among students. The implication of the results in this study is that architectural education for these data is on the right course. The schools only need to heighten the use of deep learning approaches.

The results have also shown that the use of learning approach also did not differ in terms of university type. Similarly, Ayalp (2015) studied disparities in learning approaches among three universities and revealed no differences in learning approach scores. The result is, however, contrary to that of Colak and Kaya (2014) who found that school type influences student learning approaches. The lack of difference in learning approaches based on university type could be due to the similarities of curriculum which is centrally controlled by the Nigeria University Commission (NUC). The implication is that common measures could be adopted across the two universities in fostering appropriate student learning approaches.

The results have further shown that learning approaches of the students did not differ by gender. This is similar to the findings of Hussin et al. (2017) who used a sample of engineering students and also to Kamath et al. (2018) using a sample of medical students. This is, however, contrary to the report of Arsaythamby et al. (2015) in a study carried out on a sample of English undergraduate students. The lack of gender difference in learning approaches of architecture students could mean that architectural educators need not bother about evolving special instructional methods that will avoid gender bias in the learning approaches of the students.

The results of the study have also revealed that deep learning approach positively impacts the academic performance of the students. This is both directly and even when demographic variables like university type and gender are acting as intervening variables. This is in line with Biggs's 3P theory that the process factor has a direct and indirect impact on academic performance. It is also similar to other studies like Ladan 
et al. (2014) who found learning approaches as a predictor of academic performance. This shows the importance of student approaches to academic performance. The results have further shown that, while deep leaning approaches positively impact academic achievement, surface learning approach negatively impacts academic achievement. This is similar to the findings of Lizzio, Wilson and Simons (2002) and Moore (2015) that university students with deep learning approaches obtain higher grades in academic performance. Such is also the finding of Belaineh (2017). This implies that both architectural educators and students, in order to facilitate success in examinations that will enable their students to graduate on time, should adopt instructional strategies that would encourage deep learning approaches of architecture students. According to Moh'd et al. (2015), when instructors fail to actively involve students in class discussions, students tend to apply rote learning, which hinders them from acquiring critical thinking skills. Al-Busaidi, Yusuf and Reinders (2021) reported that research has also established collaboration, which promotes a deep learning approach can be achieved in the classroom through the introduction of problem-based learning. Tee-Meng (2016) has suggested that some of the techniques instructors could adopt in order to assist students imbibe deep learning approaches include role playing, and small and large group discussions. Additionally, teachers in architectural education should also ensure that the assessment and evaluation is tailored to align with the desire for the adoption of deep learning approaches. Furthermore, universities should also ensure that workload for the students should allow the students to engage enough time in explaining ideas and developing interest in their studies. The problem of the distraction of academic programmes, which in the Nigerian experience is mainly caused by incessant strikes in the Nigerian university education, should be seriously discouraged. It affects student workload, which adversely discourages the students' adoption of deep learning approaches in their studies.

\section{Conclusion}

The study has examined the predominant learning approaches of architectural students of two public universities in Nigeria in sub-Saharan Africa. The study has identified the deep learning approach as the predominant approach for the architecture students studied. Furthermore, the study has shown that student learning approaches do not differ in terms of gender and university type. The study had the overarching aim of establishing whether there exists any impact of architecture students' learning approaches on academic performance with a view of suggesting ways that will ensure success in examinations in architectural education. This will undoubtedly facilitate their graduation on time. The study has, therefore, shown that students' learning approach has an impact on their academic performance. Also that, while deep learning approach positively affects academic performance, surface learning negatively affects academic performance. The study, however, has a sample that involved only public universities and even so from a location that is restricted in a particular part of the country, Nigeria. There is need to use bigger and more heterogeneous samples for future research that would involve private universities as well. Accordingly, this study serves as the research base for a study the researcher intends to carry out on the entire Southsouth geo-political zone in Nigeria. Furthermore, there is need to carryout qualitative studies to further confirm the quantitative results in the study. This is on the premise that some researchers have 
claimed that a mixed research that combines qualitative and quantitative results could be more valid (Lochmiller \& Lester, 2017).

Acknowledgements: The authors are thankful to all partners; architecture students of RSU and UNIUYO; lecturers in the architecture department of RSU and UNIUYO; and all members of the research team who supported our study.

\section{References}

Al-Busaidi, S., Yusuf, T., \& Reinders, H. (2021). A model for implementing problem-based language learning: experience from a seven-year journey. International Journal of Learning, Teaching and Educational Research, 20(1),1-21. https://doi.org/10.26803/ijlter.20.1.1

Arsaythamby, V., Hariharan, N., Krishnasamy, H., \& Harun, M. (2015). What are the learning approaches applied by undergraduate students in English process writing based on gender?. International Education Studies, 8(6), 50-54. https://doi.org/10.5539/ies.v8n6p46

Arteche, A., Chamorro-Premuzic, T., Ackerman, P., \& Furnham, A. (2009). Typical intellectual engagement as a by product of openness, learning approaches, and self-assessedintelligence. Educational Psychology, 29(3), 357-367.

https:// doi.org/10.1080/01443410902927833

Ayalp, G. G. (2015). Relationships between learning approaches of civil engineering undergraduate in three Turkish universities and success in construction management courses. International Journal of Engineering Education, 31(6A), 154-251.

Belaineh, M. S. (2017). Students' conception of learning environment and their approach to learning and its implication on quality education. Educational Research and Reviews, 12, 14-16. https://doi.org/10.5897/ERR2017.3258

Biggs, J. B. (1987). Student approaches to learning and studying. Australian Council for Educational Research.

Biggs, J. B., Kember, D., \& Leung, D.Y. (2001). The revised two factor study process questionnaire: R-SPQ-2F. British Journal of Educational Psychology, 71, 133-149. https://doi.org/10.1348/000709901158433

Biggs, J. B., \& Tang C. (2007). Teaching for quality learning at university (3rd ed.). Berkshire: Open University Press.

Bonsaksen, T., Brown, T., Fong, K. N., Lan, T. H., Murdolo, Y., Gonzalez, P. C., \& Beng, L. H. (2017). Approaches to learning among occupational therapy undergraduate students: A cross-cultural study. Scandinavian Journal of Occupational Therapy, 24(4), 299-310. https://doi.org/10.1080/11038128.2016.1229811

Carstensen, T., Ødegaard, N. B., \& Bonsaksen, T. (2018). Approaches to studying: Associations with learning conceptions and preferences for teaching, cogent education. Journal of Social Science Research, 6(1), 746-752.

Cetin, B. (2016). Approaches to learning and age in predicting college students' academic achievement. Journal of College Teaching and Learning (TLC), 13(1), 21-28. https//doi. org/10.19030/tlc.v13i1.9568

Chonkar, S. P., Ha, T. C., \& Chu, S. H. (2018). The predominant learning approaches of medical students. BMC Medical Education, 18(17), 11-25. https://doi.org/10.1186/s12909-018$1122-5$

Choy, J. L. F., O'Grady, G., \& Rotgans, J. I. (2012). Is the Study Process Questionnaire (SPQ) a good predictor of academic achievement? Examining the mediating role of achievement-related classroom behaviours. Instructional Science, 40, 159-172. https://doi.org/10.1007/s11251-011-9171-8. 
Colak, E., \& Kaya, D. (2014). Learning approaches of vocational high school students: grade level and school type influences. Procedia-Social and Behavioral Sciences, 116(15), 15561561. https://doi.org/10.1016/j.sbspro.2014.01.434

Danaci, H. M. (2014). Creativity and knowledge in architecture education. Procedia - Social and Behavioural Science, 174, 1309 -1312. https://doi.org/10.1016/j.sbspro.2015.01.752

Dilek, I. B., \& Noor, S. (2015). Learning approaches of successful students and factors affecting their learning approaches. Education and Science, 40(17), 193-216. https://doi.org/10.15390/EB.2015.4214

Entwistle, N. (1988). Motivational factors in students' approaches to learning. Learning strategies and learning style. New York: Plenum Press.

Howie, P., \& Bagnell, R. (2013). A critique of the deep and surface approaches to learning model and teaching. Journal of Higher Education, 18(4), 389-400. https://doi.org/10.1080/13562517.2012.733689

Hussin, F., Hamed, S., \& Md-Jam, S. (2017). Approaches to learning of engineering students: Deep or surface? International Academic Research Journal of Social Science, 3(1), 122-127.

Kamath, A., Rao, R. R., Shenoy, P. J., \& Ullal, S. D. (2018). Approaches to learning and academic performance in pharmacology among second-year undergraduate medical students. Journal of Medical Science, 28, 4-23. https:/ / doi.org/10.15448/1980-6108.2018

Karagiannopoulou, E., \& Milienos, F. S. (2015). Testing two path models to explore relationships between students' experiences of the teaching-learning environment, approaches to learning and academic achievement. International Journal of Experimental Educational Psychology, 35(1), 26-52. https://doi.org/10.1080/01443410.2014.895800

Keithia, L., Wilson, R., Smart, M. J., \& Robert, W. (2011).Gender differences in approaches to learning in first year psychology students. British Journal of Educational Psychology, 66(1), 59-71. https://doi.org/10.1111/j.2044-8279.1996.tb01176.x

Khan, A. A., Asimiran, S., Kadir, S. A., Alias, S. N., Atta, B., Bularafa, B. A., \& Rehman, M. U. (2020). International Journal of Learning, Teaching and Educational Research, 19(10), 233247. https://doi.org/10.26803/ijlter.19.10.13

Ladan, M. A., Balarabe, F., Sani, D. K., Musa, H. A., \& Salihu A. A. (2014). Learning approaches as predictors of academic performance of undergraduate students in Ahmadu Bello University, Zaria. Journal of Nursing and Health Science, 3(3), 45-50. https://doi.org/10.9790/1959-03344550

Leung, M., Li, J., Fang, Z., \& Lu, M. (2015). Learning approaches of construction engineering students: A comparative study between Honk-Kong and Mainland China. Journal of Education in the Built Environment, 1(1), 112-131. https://doi.org/10.11120/jebe.2006.01010112

Lizzio, A., Wilson, K., \& Simons, R. (2002). University students' perceptions of the learning environment and academic outcomes: implications for theory and practice. Studies in Higher Education, 27(1), 27-52. https:// doi.org/10.1080/03075070120099359

Lochmiller, C. R., \& Lester, J. N. (2017). An introduction to research connecting methods to practices. London. Sage Publications Inc.

Moh'd, T., Nor, A., Othman, A., Hamid, M. Y., Ibrahim, N. A., Ismail, N. A., Hamimi, A., \& Tharim, A. (2015). The influence of learning approach on students' academic achievement: A study on UiTM (Perak) Students. https:/ / files.eric.ed.gov/fulltext/EJ1238844.pdf

Moore, L. (2015). The relationship between approaches to learning and assessment outcomes in undergraduate optometry students [MA Dissertation, Dublin Institute of Technology]. https:/ / arrow.tudublin.ie/cgi/viewcontent.cgi?article=1033\&context=ltcdis

Noori, A. Q., Said, H. F., Nor, M., \& Ghani, F. A. (2020). The relationship between university lecturers' behavior and students' motivation. Universal Journal of Educational Research, 8(11C), 15-22. https://doi.org/10.13189/ujer.2020.082303 
Öhrstedt, M., \& Lindfors, P. (2019). First-semester students' capacity to predict academic achievement as related to approaches to learning. Journal of Further and Higher Education, 43(10), 1420-1432.

https:// doi.org/10.1080/0309877X.2018.1490950

Oluwatayo, A., Aderonmu, P., \& Aduwo, B. (2015). Architecture students' perceptions of their environment and their academic performance. Journal of Learning Environment Research, 18, 129-142.

Pallent, J. (2011). SPSS Survival Manual. Allen University Australia. https://doi.org/10.4236/oa lib.1100973

Puteh, S. M., Abdul Latif, N. E., Mansor, N., Hamid, Y. S., \& Halid, Z. (2018). Learning Approaches and Academic Performance. Journal of Social Sciences Research and Academic Research Publishing Group, 6, 746-752.

Rakibul-Islam, G., \& Shahriar Shafiq, M. (2016). Surface and deep approaches to learning in higher education. Bangladesh Journal of Educational Research, 2(1), 45-56.

Rosander, P., \& Martin, B. (2012). The unique contribution of learning approaches to academic performance, after controlling for IQ and personality: Are there gender differences? Journal of Learning and Individual Differences, 22(6), 820-826. https://doi.org/10.1016/j.lindif.2012.05.011

Salamonsun, Y., Weaver, R., Chang, S., Koch, J., Bhathal, R., Khoo, C., \& Wilson, I. (2013). Learning approaches as predictors of academic performance in first year health and science students. Nurse Education Today, 33, 729-733. https://doi.org/10.1016/j.nedt.2010.10.019

Sedgwick, P. (2014). Cross sectional studies: advantages and disadvantages. BMJ, 348:g2276. https://doi.org/10.1136/bmj.g2276

Shaik, S. A., Almarzuqi, A., Almogheer, R., Alharbi, O., Jalal, A., \&Alorainy, M. (2017). Assessing Saudi medical students learning approach using the revised two-factor study process questionnaire. International Journal of Medical Education, 8, 292-296. https://doi.org/10.5116/ijme.5974.7a06

Song, J. (2018). Elements in Mol-based College English learning environment- based on Biggs' 3P Model. Advances in social science, education and information research, 89, 5-14.

Tee-Meng, Y., Kannaki, F. D., Narayansany, S., M. Kamala, P., Manickam, S. J., \& Leong, K. (2016). Stimulating deep learning using active learning techniques, Malaysian. Online Journal of Educational Science, 4(6), 6-29.

https:// files.eric.ed.gov/fulltext/EJ1106447.pdf 


\section{APPENDIX I}

\section{SECTION A: Demographic characteristics}

Please tick as appropriate

Name of University

Gender: Male .......

Yours CGPA: (0.00-1.49)

Female.......

$(4.50-5.00)$

$(1.50-2.49)$

$(2.50-3.49)$

$(3.50-4.49)$

\section{SECTION B: STUDENTS' LEARNING APPROACHES}

Please choose the letter most appropriate to you:

A - Never or only rarely true of me (1)

B - Sometimes true of me (2)

C - True of me about half the time (3)

D -Frequently true of me (4)

E-- Always or almost always true of me (5)

\begin{tabular}{|c|c|c|c|c|c|c|}
\hline $\mathrm{S} / \mathrm{N}$ & ITEMS & A & B & C & D & $E$ \\
\hline 1 & $\begin{array}{l}\text { I find that sometimes studying gives me a feeling of } \\
\text { deep personal satisfaction. }\end{array}$ & & & & & \\
\hline 2 & $\begin{array}{l}\text { I find that I have to do enough work on a topic so } \\
\text { that I can perform my own conclusions before I am } \\
\text { satisfied. }\end{array}$ & & & & & \\
\hline 3 & $\begin{array}{l}\text { My aim is to pass the course while doing as little } \\
\text { work as possible. }\end{array}$ & & & & & \\
\hline 4 & $\begin{array}{l}\text { I only study seriously what's given out in class or in } \\
\text { the course outlines. }\end{array}$ & & & & & \\
\hline 5 & $\begin{array}{l}\text { I feel that virtually any topic can be highly interesting } \\
\text { once I get into it. }\end{array}$ & & & & & \\
\hline 6 & $\begin{array}{l}\text { I find the most new topics interesting and often } \\
\text { spend extra time trying to obtain more information } \\
\text { about them. }\end{array}$ & & & & & \\
\hline 7 & $\begin{array}{l}\text { I do not find my course very interesting so I keep my } \\
\text { work to the minimum. }\end{array}$ & & & & & \\
\hline 8 & $\begin{array}{l}\text { I learn some things by rote, going over and over them } \\
\text { until I know them by heart even if I do not } \\
\text { understand them. }\end{array}$ & & & & & \\
\hline 9 & $\begin{array}{l}\text { I find that studying academics topics can at times be } \\
\text { as exciting as a good novel or movie. }\end{array}$ & & & & & \\
\hline 10 & $\begin{array}{l}\text { I test myself on important topics until I understand } \\
\text { them completely. }\end{array}$ & & & & & \\
\hline 11 & $\begin{array}{l}\text { I find I can get by in most assessments by } \\
\text { memorizing key sections rather than trying to } \\
\text { understand them. }\end{array}$ & & & & & \\
\hline
\end{tabular}




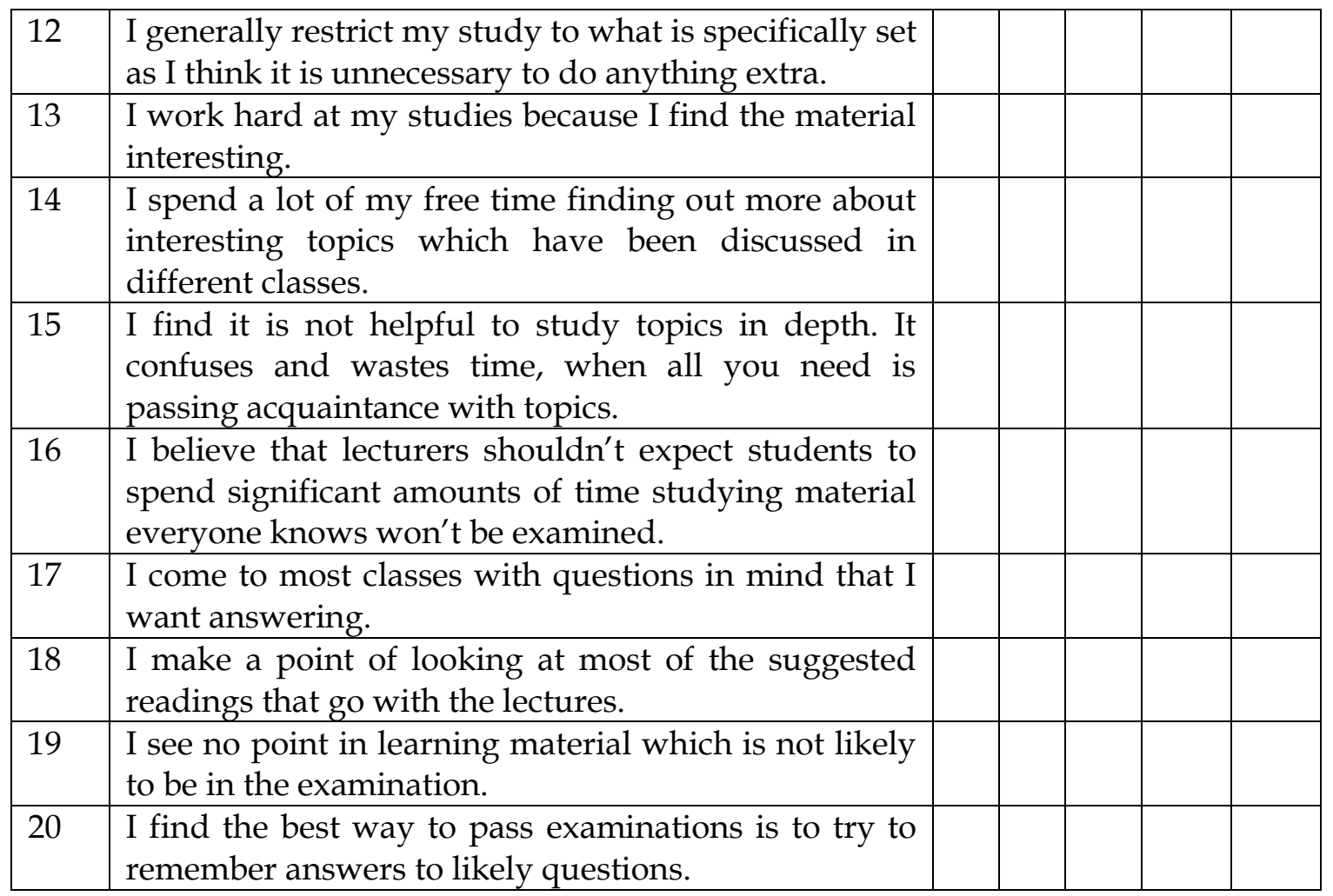

Scoring is the following cyclical order:

Deep Motive, 2. Deep Strategy,3. Surface Motive, 4. Surface Strategy 5. etc.

Deep Approach Score: $\quad \sum$ All Deep Motive scores + all Deep Strategy sores

Surface Approach Score: $\quad \sum$ All Surface Motive scores + all Surface Strategy scores. 